\title{
A NEW STIZUS FROM UTAH, WITH NOTES ON THE OTHER NORTH AMERICAN SPECIES \\ (HYM.: SPHECID AE)
}

\author{
BY RICHARD DOW
}

Reading, Mass.

\section{Stizus iridis, sp. nov.}

Male.- Length about $20 \mathrm{~mm}$. Yellow (Amber Yellow of Ridgway), with the following exceptions: mandibles dark ferruginous at apex with a ferruginous line along the interior margin; supra-antennal area with inconspicuous dark spots on each side; a broad transverse black band across the vertex including the ocelli, with an anterior extension along the median frontal groove; occiput with two black or ferruginous bands which connect the sides of the vertex with an extensive black area surrounding the foramen; antennæ with the posterior surface of the scape, the pedicel, and the flagellum ferruginous, the flagellum shading to black above and to orange toward the apex; pronotum with a black transverse band anteriorly; disk of mesoscutum and anterior margin between posterior lobes of pronotum black, either marked with two narrow yellowish longitudinal stripes (holotype), or two large spots of reddish brown (paratype), or simply black (paratype); dorsal surface of propodeum with a narrow black fascia along the anterior margin, wider and with a posterior median projection in the paratypes; sutures of propodeal area marked with black lines (partly obsolete in the holotype) which meet on the posterior surface; posterior surface with a black line extending anteriorly along the median groove; proepisterna black except for a small spot near the lateral angle of each front coxa; mesosternum with a large black maculation, medially interrupted in both paratypes, and ferruginous in one of them, emarginate (holotype) or narrowed anteriorly, but posteriorly with only a narrow 
separation (along the ridge representing the mesopleural suture) from a dark spot near the ventral end of the meso-metapleural suture; remainder of mesopleura, except dorsal portion of mesepisterna, suffused with orange; mesometapleural and metapleural-propodeal sutures marked with black lines; lateral areas of metasternum black; all coxæ black at base, at least anteriorly ; remainder of legs partially suffused with orange; veins and membrane of fore wings yellowish basally, and somewhat fuliginous in the region of the first submarginal and marginal cells, the latter with a dark streak in the anterior half; hind wings yellowish; anterior face of first tergite more or less ferruginous, with a black basal area which (in the holotype and one paratype) has a narrow median projection and broad extensions at the sides (the other paratype has only a median projection which is shorter and does not reach the dorsal surface) ; apical and to some extent the lateral margins of all tergites orange; basal margins of tergites 2-5 orange or black (always black on tergites 4-5), each with a triangular median projection of the same color; sternites variously marked with orange and black.

Head (in facial view) broader than long, the posterior margin nearly straight; inner margins of eyes nearly straight, slightly converging anteriorly, nearest to each other where they reach the clypeus; clypeus emarginate both anteriorly and posteriorly (fig. 1), the peak of its convexity (seen in profile) anterior to the middle; supraclypeal area posteriorly three times as broad as long, the sutures defining the frontal shield (Stirnschildschen) not distinct; antennal sockets separated from the eyes and from each other by somewhat less than their transverse diameter; space between the antennal sockets with a low ridge, carinate posteriorly; supra-antennal area with a broad median impression which extends posteriorly and encircles the anterior ocellus; posterior ocelli smaller than the anterior ocellus, separated from the eyes by one and a half times their diameter, and from each other by twice their diameter; latero-posterior margins of each posterior ocellus bordered by an impressed line which continues posteriorly in a medially concave curve to the vertical face of the occiput; genæ (in lateral view) rather narrow, wider below. Man- 
dibles with a small tooth near the apex. Antennæ long enough to reach the posterior face of the propodeum; segments 9-12 much shorter than the four preceding, 9 about
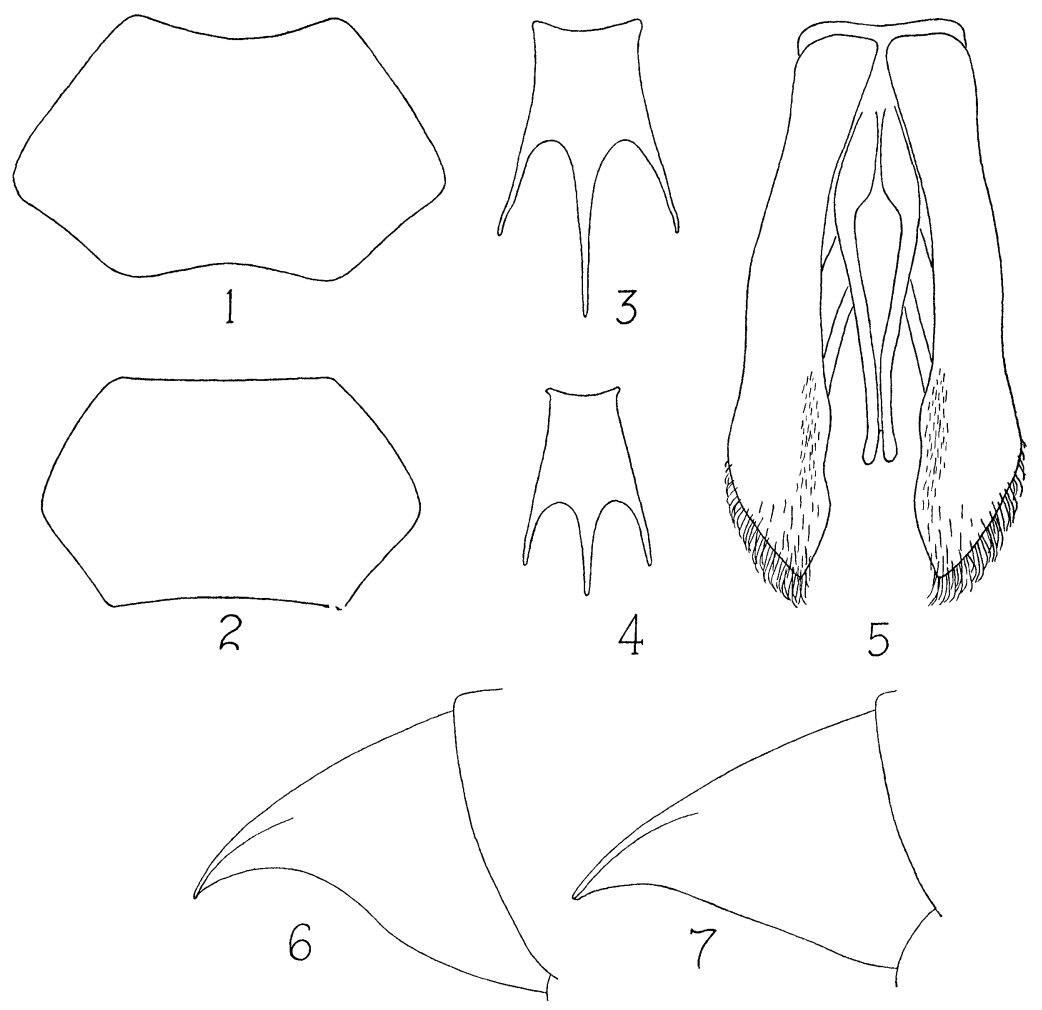

Figure 1. Clypeus of Stizus iridis, sp. nov.

Figure 2. Clypeus of Stizus occidentalis Parker (holotype male).

Figure 3. Eighth sternite of Stizus iridis, sp. nov.

Figure 4. Eighth sternite of Stizus occidentalis Parker (holotype male).

Figure 5. Male genitalia of Stizus iridis, sp. nov.

Figure 6. Sixth tergite of Stizus brevipennis, lateral outline.

Figure 7. Sixth tergite of Stizus texanus, lateral outline.

two-thirds as long as 8, 13 tapering to a round end and not emarginate within; tyloids present as linear carinæ on segments $6-13$, that on 5 very short, practically a tubercle. 
Thorax (in dorsal view) somewhat rectangular; pronotum not elongate; parapsidal furrows not extended to the posterior margin of the mesoscutum, each represented by a slender carina with an extremely fine longitudinal impression; sutures defining the propodeal area strongly impressed; meso-metapleural suture sinuous, but not strongly curved anteriorly; hind angles of the propodeum tumid. Fore wings 17-18 $\mathrm{mm}$. long, about four times as long as the distance between the posterior lateral angles of the mesoscutum, the first transverse cubital vein practically straight. Legs slender.

Abdomen large and elongate; first tergite with a flattened anterior face, in dorsal aspect roundly angulate anteriorly, the concave sides (as seen from above) parallel towards the base, diverging posteriorly.

The puncturation is fairly coarse and dense over most of the body. The clypeus and supraclypeal area, however, are very finely punctate, and anterior to the black band across the vertex are two areas with coarse, well-separated punctures.

The pubescence is pale and generally distributed, but longer, or at least more conspicuous, on the posterior half of the clypeus, the sides of the supraclypeal area, the anterior portion of the supra-antennal area, the vertex and the adjacent occiput, the lower portion of the genæ, the lower portion of the mesopleura, the mesosternum, the posterior angles of the propodeum, and the first tergite.

Female.-Unknown.

Types.- Holotype, Museum of Comparative Zoölogy, Cambridge, No. 23397. One paratype, U. S. National Museum, No. 55828. One paratype in the author's collection.

Type locality.- Rainbow Bridge National Monument, San Juan County, Utah.

Distribution.- Holotype male and two male paratypes taken at the type locality, July 16, 1935, by Professor C. T. Brues, who kindly supplied the following notes.

"The specimens of the new Stizus were collected in the canyon about half a mile above Rainbow Natural Bridge near the camp established for visitors. Close to the open space in which the camp is situated are cliffs that form one 
of the cavelike hollows characteristic of the red sandstone of this region. In the early morning, over the steep talus slope to one side of this 'cave,' still in the shadow of the high cliff on the east, great numbers of these wasps were circling and darting about. In their erratic flight they would scarcely ever pause, and it was only after considerable effort that I finally secured three specimens. They did not appear at all wary and had it not been for the very insecure nature of the steep slope and loose rocks, they would have been taken quite easily. The wasps soon disappeared, long before any sunshine reached the spot. There was practically no vegetation on the slope where the wasps were observed."

Remarks.- The present species of Stizus is the fourth of the genus (as now restricted) to be described from North America. Of the remaining three it is most closely related to occidentalis Parker, a member of the ruficornis group. The male of the new species, like that of occidentalis, has the first transverse cubital vein practically straight, not evenly curved toward the apex of the wing. If the female should prove to have a scutellar pit (as it does in occidentalis), iridis may be assigned to the ruficornis group without question.

The types of iridis have been compared with the holotype male of occidentalis, which differs in the following structural details. In the holotype of occidentalis the clypeus is evenly convex in profile; it has a wider emargination anteriorly and the posterior margin is practically straight (fig. 2). Lateral to each posterior ocellus of the holotype of occidentalis, there is a longitudinal shining impression, about one-third the diameter of the ocellus in width; it extends posteriorly for a distance about equal to the diameter of the ocellus, but does not descend the vertical face of the occiput. Behind the anterior ocellus there is no circular impression. Linear tyloids are present on antennal segments 7-13, instead of 6-13 as in iridis; on the right antenna they are all conspicuous, but on the left less so, particularly on 7 and 8 . In dorsal aspect the thorax appears more rounded anteriorly, and more pointed behind. The parapsidal furrows are represented by simple impressed lines. The posterior angles of the propodeum are less convex than in iridis, and the sutures defining the propodeal area are not 
strongly impressed. The first tergite is distinctly rounded in dorsal aspect, and has a less sharply marked anterior face. Other structural differences occur in the eighth sternite (figs. 3 and 4) and the parameres of the genitalia (compare fig. 5 with Parker's fig. 29).

The author discovered another genitalic character while comparing his paratype of iridis with two males of occidentalis kindly loaned by Dr. C. D. Michener. In occidentalis the compressed shaft of the digitus, when viewed laterally, is rather uniform in width, but in iridis its ventral margin is strongly emarginate.

\section{Stizus occidentalis Parker}

1929. Stizus occidentalis Parker, Proc. U. S. Nat. Mus. 75 (5) : 9, pl. 4, fig. 29. 오, ㅇ․

This species was described from two specimens: a male from "San Diego County," California, collected by Coquillett, and a female from Florence, Arizona. As a result of the present author's recent trip to California, six additional specimens were located in various collections. This material, which considerably extends the known range, indicates that occidentalis is a desert species of the Lower Austral Region, and suggests that the holotype collected by Coquillett may really have been taken in what is now Imperial County, formerly the eastern part of San Diego County.

CALIForNIA: Panamint Mts., Inyo Co.; May 29, 1937; N. W. Frazier, 1 ô [California Academy of Sciences]. Wild Rose Canyon, Panamint Mts., Inyo Co.; elevation, $3000 \mathrm{ft}$; flying about flowers of Prosopis chilensis in noonday sunlight; May 28, 1937; C. D. Michener; 2 ô, 1 우 [C. D. Michener]. Furnace Creek, Death Valley; on Pluchea sericea; May 1, 1927; P. H. Timberlake; 1 ㅇ [University of California Citrus Experiment Station]. Eight miles south of Needles; on Acacia greggii; June 4, 1938; P. H. Timberlake; 1 \& [University of California Citrus Experiment Station].

\section{Stizus brevipennis Walsh}

1869. Stizus brevipennis Walsh, Amer. Entomologist 1: 162. ô. 
1875. Larra brendeli Taschenberg, Zeitschr. f. d. Ges. Naturwiss. 45: 361. ô.

1879. Megastizus brevipennis Patton, Bull. U. S. Geol. Survey Terr. 5: 345 . 상, ㅇ․

1887. Megastizus brevipennis Cresson (pars), Synopsis: 278.

1892. Stizus brevipennis Handlirsch, Sitz. Akad. Wiss. Wien, Math.-nat. Cl., 101 (1) : 174, pl. 1, fig. 13, pl. 2, fig. 28, pl. 3, fig. 15. ô, 오 .

1895. Stizus brevipennis Fox, Proc. Acad. Nat. Sci. Philadelphia 1895: 266-268. 소, ㅇ․

1941. Megastizus brevipennis Snodgrass, Smiths. Misc. Coll. 99 (14) : pl. 19, figs. A-G. ô.

The only published information relative to the prey of the North American species of Stizus is a brief note by F. X. Williams (1913, Kansas Univ. Sci. Bull. 8 (4) : 198) to the effect that brevipennis "hunts in a manner quite similar to [Tachytes] mandibularis, examining the stems of Helianthus, etc., as she flies and finally finds her prey, a large Xiphidium." Dr. Williams has informed the author (in litt.) that the grasshopper in question is "a large shortwinged adult $q$ of Xiphidium, now known as Conocephalus. It has a long, rather straight, ovipositor." In the selection of Orthoptera as prey, brevipennis agrees with the Old World species of Stizus, which, with two doubtful exceptions, have thus far been reported to capture either grasshoppers or mantids.

The male of brevipennis is very distinct from that of texanus. Besides the characters given in the accompanying key, the genitalia are entirely different. The females of these species are less readily distinguished, and as the pygidial character given by W. J. Fox does not appear to be valid, the present author has substituted another character of the sixth tergite which is quite satisfactory.

In the following list of specimens examined by the author, the record for Indian Head, Maryland, is by far the most surprising. It would certainly appear to be in error were it not for the occurrence of the species in central Florida.

FlORIDA: Cape Barrancas; C. Willard; 1 \% [M.C.Z.]. 
Gainesville; July 7 to 22, 1918; P. W. Fattig; 5 o [U.S.N.M.].

\section{ILLINOIS : 2 ô [A.M.N.H.].}

IowA: Mount Pleasant; July 1920; 1 \& [U.S.N.M.].

KANSAS : 1 \% [U.S.N.M.]. Douglas Co.; 900 ft.; F. H. Snow; 1 ô [U.S.N.M.]. Riley Co.; July 9 and 31; Popenoe; 1 \& and 1 ô [U.S.N.M.]. Dickinson Co.; August; Bridwell; 1 \& [U.S.N.M.]. Wellington; H. R. Watts; 1 \% [U.S.N.M.].

MARYLAND: Indian Head; August 23, 1902; Bridwell; 1 ô [U.S.N.M.].

MIsSOURI: St. Louis ; July 1911; P. Rau ; 1 \& [U.S.N.M.].

Nebraska: Cambridge; July 26, 1921, August 2, 1921, and August 22, 1923; A. P. Morse; 1 ㅇ, 1 is [M.C.Z.], and 1 ô [Richard Dow].

OKLahoma: Ardmore; July 11, and August 18, 1905; C. R. Jones; 1 is and 1 ㅇ [U.S.N.M.].

South Dakota: Springfield; August 27, 1926; H. C. Severin; 1 ô [M.C.Z.].

TEXAS: Belfrage [collector]; 1 ô, 1 क [U.S.N.M.]. San Antonio; H. B. Parks; 1 ô [U.S.N.M.].

WISCONSIN : Milwaukee; August 12, 1907; S. Graenicher ; 1 ô $[$ [M.C.Z.].

\section{Stizus texanus Cresson}

1872. Stizus texanus Cresson, Trans. Am. Ent. Soc. 4: 222. ô, ㅇ. .

1879. Megastizus texanus Patton, Bull. U. S. Geol. Survey Terr. 5: 345 . ô, ㅇ. .

1887. Megastizus brevipennis Cresson (pars), Synopsis: 278.

1892. Stizus texanus Handlirsch, Sitz. Akad. Wiss. Wien, Math.-nat. Cl., 101 (1) : 176, pl. 1, figs. 6, 14, 15, pl. 2; fig. 29, pl. 3, fig. 16 . ô, ㅇ.

1895. Stizus texanus Fox, Proc. Acad. Nat. Sci. Philadelphia 1895: 267-268. 수, ㅇ. .

In the American Museum of Natural History there is a female of texanus from Tucson, Arizona, a locality con- 
siderably west of the previously known range of the species. Though the head and thorax are normal in coloration, the abdomen is remarkable for the extent of the yellow maculations. Whereas the lateral spots on tergites 3 and 4 are usually well separated in texanus, in this specimen they are united medially to form broad continuous fasciæ, the first of which is deeply emarginate anteriorly, but the second less so. There is also a broad fascia on tergite 5 which covers most of the exposed portion of the sclerite. Even the yellow spots on sternites 2,3 , and 4 are exceptionally large.

The following records are of specimens examined by the author.

ARIZONA: Tucson; "Creosote bush assn."; August 6, 1906 ; G. von Krockow ; 1 \% [A.M.N.H.].

TeXas: 2 î [M.C.Z.]. Lincecum [collector]; 1 \% [M.C.Z.]. Alpine; June 4, 1927 [?]; 1 ô [U.S.N.M.]. Cotulla; June 21, 1906 ; H. Caley; 1 ô, 4 ㅇ [U.S.N.M.]. "Dallas"; Boll; 9 ô, 9 ㅇ [M.C.Z.] and 1 ô [Richard Dow]. Laredo; May 16, 1924; 2 \& [U.S.N.M.]. San Antonio: May 27, 1937; 3 is [U.S.N.M.].

In the following key to the known forms of Stizus occurring in North America, the author is following the division of the Stizini proposed by J. B. Parker in 1929 (Proc. U. S. Nat. Mus. 75 (5): 7-11). According to this classification, Stizus unicinctus Say belongs in the genus Stizoïdes (equivalent to the tridentatus group of Handlirsch, Berland, and Arnold), and the genus Bembecinus includes the forms with a concave propodeum. The name Megastizus is applicable to Stizus brevipennis and texanus, but whether these species form a group worthy of subgeneric rank is a question the author prefers to leave undecided until he has studied more material from other regions.

1. Males 2.

Females

5.

2. Antennæ without longitudinal carinæ on segments 9 and 10. Seventh tergite with large ventral lobes.......... 3. Antennæ with longitudinal carinæ on segments 9 and 10. Seventh tergite without large ventral lobes 4. 
3. Anterior margin of clypeus laterally with blunt teeth, its shallow nearly straight emargination with two low projections. Narrowed apex of seventh tergite broadly rounded; ventral lobes of seventh tergite broad, about twice as long as wide, broadly triangular at apex. Apex of seventh sternite broadly triangular, the more heavily sclerotized portion spear-shaped. Median spine of eighth sternite borne on a spearshaped projection much narrower than the basal portion brevipennis Walsh

Anterior margin of clypeus evenly rounded. Apex of seventh tergite narrowed into a flattened truncate projection with a small but distinct median emargination; ventral lobes of seventh tergite slender, nearly three times as long as wide, narrowly triangular at apex. Seventh sternite narrowly triangular, truncate at apex, the more heavily sclerotized portion of similar shape. Median spine of eighth sternite on a broad triangular projection texanus Cress.

4. Posterior margin of clypeus practically straight. Antennal segments 7-13 with distinct tyloids. Sides of first tergite (in dorsal view) slightly convex. Thorax conspicuously hairy. Mesopleura, metapleura, and propodeum mostly or entirely black occidentalis Parker

Posterior margin of clypeus emarginate. Antennal segments 6-13 with distinct tyloids. Sides of first tergite (in dorsal view) concave. Thorax not conspicuously hairy. Mesopleura, metapleura, and propodeum almost entirely yellow ................iridis, sp. nov.

5. Sixth tergite with a pygidial area

6.

Sixth tergite without a pygidial area defined by lateral ridges. Posterior margin of clypeus practically straight. Lateral margins of first tergite slightly convex. Thorax conspicuously hairy. Mesopleura, metapleura, and propodeum mostly or entirely black occidentalis Parker 
6. Anterior margin of clypeus with a broadly V-shaped emargination. Lateral margins of sixth tergite strongly sinuous (fig. 6) ...................brevipennis Walsh

Anterior margin of clypeus with a shallow rounded emargination. Lateral margins of sixth tergite with the basal three-quarters nearly straight (fig. 7) texanus Cress.

Acknowledgments. - The author is much obliged to the numerous entomologists and museums whose material he has been permitted to study, and especially to Professor Brues for the privilege of describing the new species and permission to retain one of the paratypes. For assistance in the preparation of this paper, he is greatly indebted to the late Miss Grace A. Sandhouse and to Mr. Karl V. Krombein, both of the Bureau of Entomology and Plant Quarantine. 

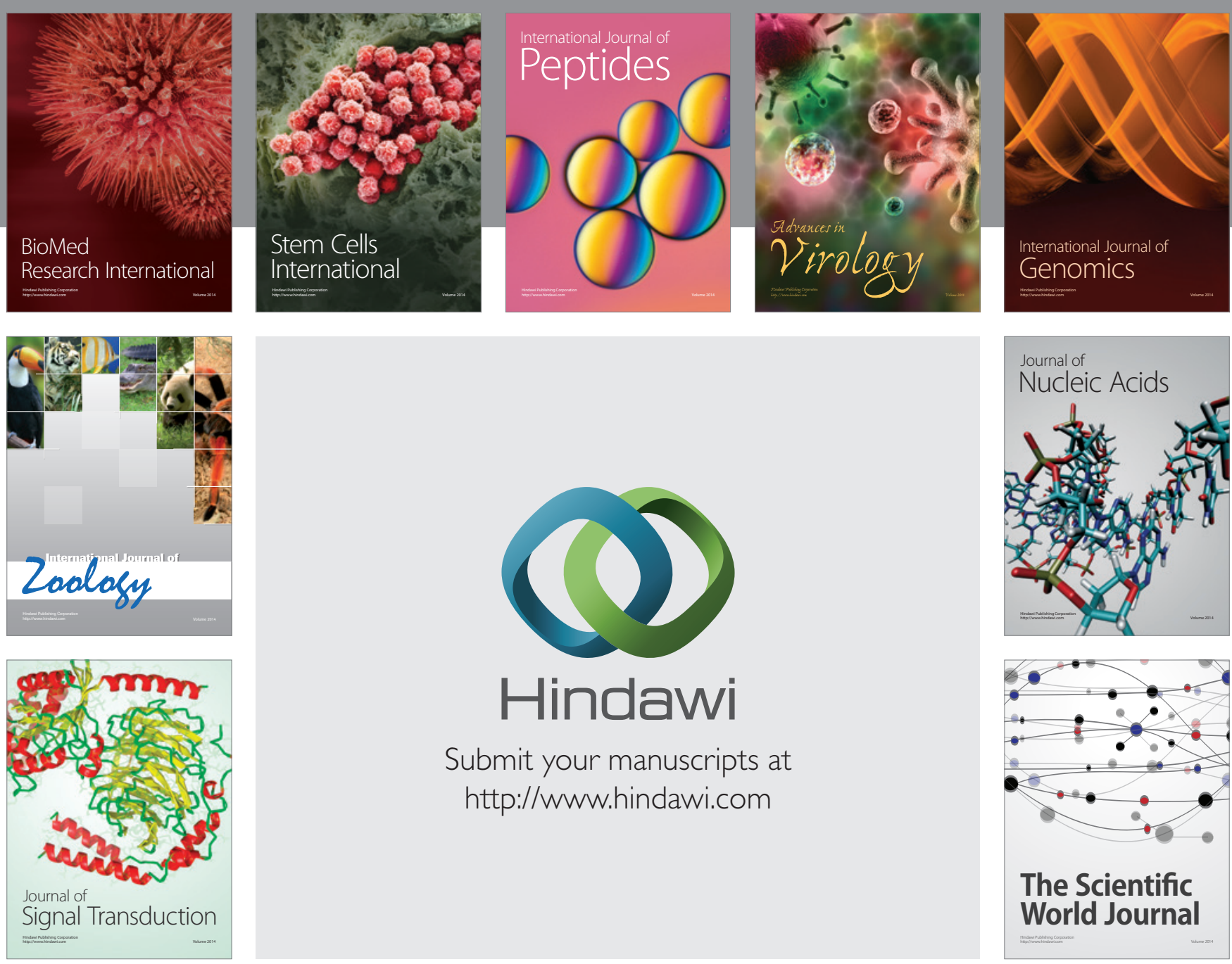

Submit your manuscripts at

http://www.hindawi.com
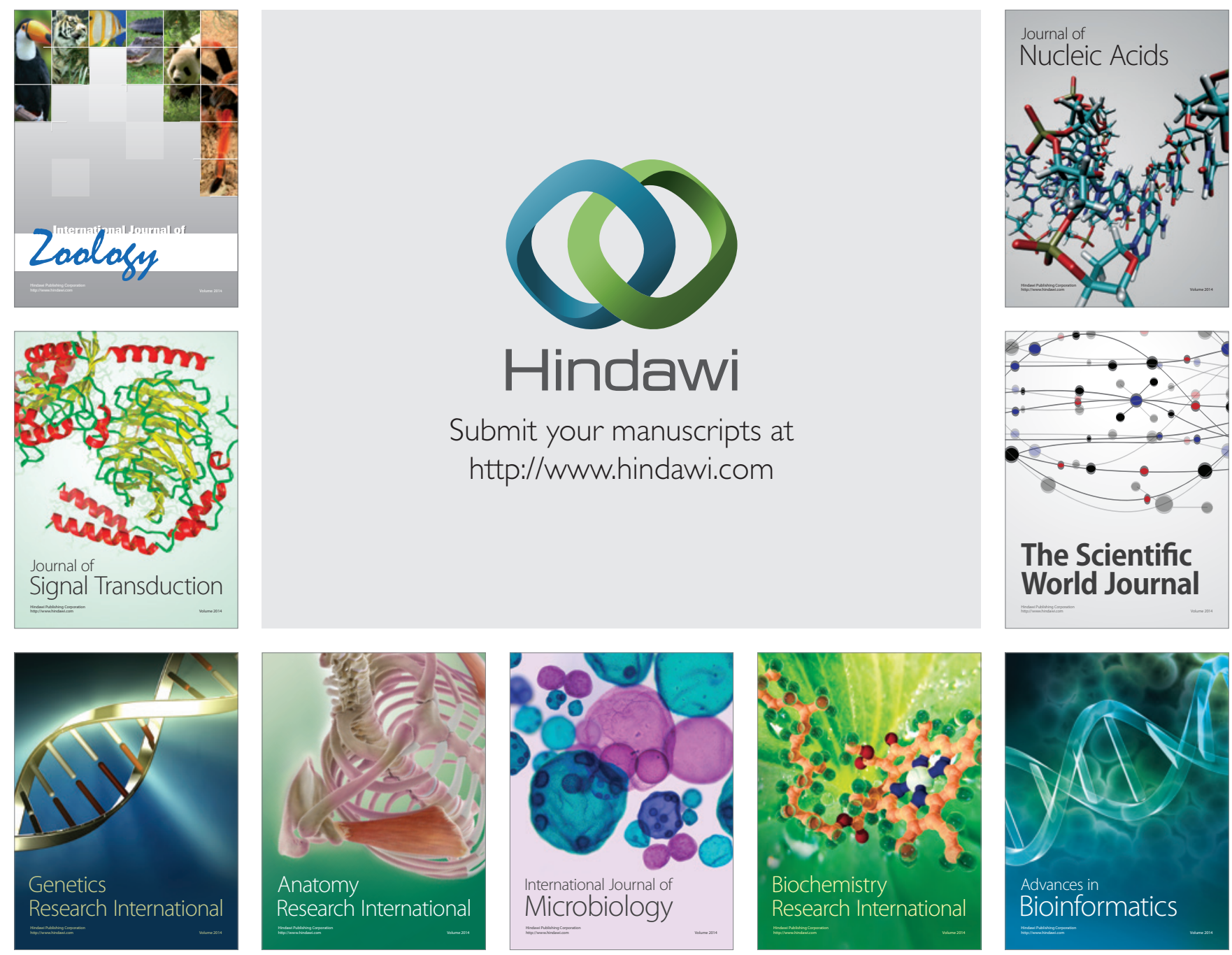

The Scientific World Journal
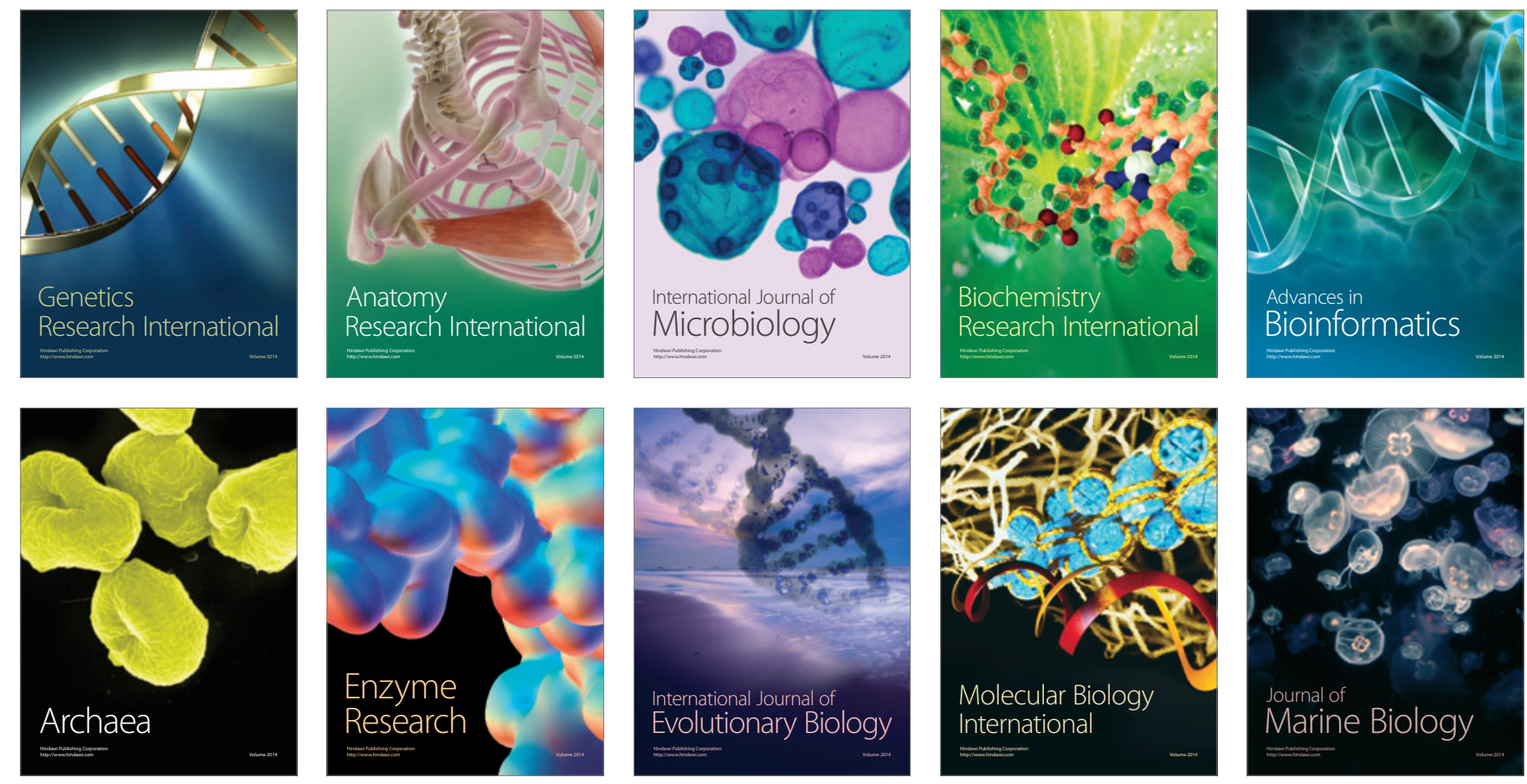